International Journal of

Advanced Science and Convergence

\title{
The Application Example Analysis of TOD in Railroad Station Area and its Implicative Urban Policy Direction
}

\author{
Eun-Yeol Oh${ }^{1}$ \\ ${ }^{1}$ Professor, Department of Urban Design Information Engineering, Sungkyul University, Anyang, Gyeonggido, \\ Republic of Korea
}

\begin{abstract}
Background/Objectives: TODs can also have a direct impact on urban development and maintenance in station areas, from which point of view TODs can establish complex land use as a major means. The purpose of this is to set urban policy goals and present urban policy directions by classifying them into urban planning and transportation planning dimensions. Methods/Statistical analysis: In this paper, we are going to draw implications based on the analysis of domestic and overseas TOD application cases and qualitative characteristics in presenting urban policy directions through land use and public transportation elements, which are the main characteristics of TOD. Findings: Based on the results of the study, it was derived that the urban planning dimension requires longitudinal requirements to apply TOD through adjustment of the use area, and that the public transportation zone designation and traffic stabilization technique can be applied as a transportation demand management technique. Improvements/Applications: It is believed that further analytical research on the development and application effects of TOD-specific techniques will be required in the future.
\end{abstract}

\section{Index Terms}

Transit-Oriented Development, Railroad Station Area, Mixed Land Use, Land Use Elements, Public Transportation Elements

\footnotetext{
Corresponding author : Eunyeol Oh

oesh21@naver.com

- Manuscript received May 27, 2021.

- Revised June 10, 2021 ; Accepted June 20, 2021.

- Date of publication June 30, 2021.

(c) The Academic Society of Convergence Science Inc.

2619-8150 @ 2019 IJASC. Personal use is permitted, but republication/redistribution requires IJASC permission.
} 


\section{INTRODUCTION}

This document Prior to the introduction of the concept of Transit Oriented Development (TOD) in Korea, a station area development project similar to TOD was developed around railway stations. The development of station influence areas is a project to develop service facilities, etc. in railway stations or adjust the attraction function to develop urban areas around stations in order to induce smooth connection between other means of transportation.

Therefore, the development of the station area is closely related to TOD in that it is developed around railway stations, which are public transport nodules, with complex land use as the main means. Since the late 1990s, interest in TOD, including the development of station influence areas, has increased in Korea, and related research has been gradually carried out. In particular, the application of TOD to station areas in the high-speed railway era is expected to increase the attractiveness of local city locations and directly affect urban development and maintenance.

In this paper, we analyze cases of TOD application in domestic and foreign stations to derive policy implications. Therefore, the purpose of the paper is to analyze the application of TOD in domestic and foreign station areas, focusing on the land use and public transportation characteristics of TOD, and to present the urban policy direction of TOD in terms of planning and system. Domestic and foreign cases were collected and analyzed by reviewing existing documents, analyzing statistical data, and searching related Internet websites.

Looking at the main content of the study, Chapter I introduced the background, purpose, and method of the study. In Chapter 2, we explore the overall theoretical overview of TOD, and review existing research trends through prior study materials. Chapter 3 mainly classified high-speed railway station areas and urban development aspects to identify domestic and foreign applications of TOD. Chapter 4 presents the direction of urban policy for TOD application in terms of urban planning and transportation planning, and Chapter 5 summarizes the research results in the conclusion.

\section{LiteratURE REVIEW}

In Korea, TOD is still partially promoted in connection with the development of station influence areas. In the early days, conceptual research on station area development was mainly focused. Recently, research on the development of station influence areas has been conducted on public transport nodules, including buses and other public transportation as well as station influence areas. Baek Gyeong-moo (2000) conducted a study on public transportation-oriented development plans. In order to help him understand the development of public transportation, he introduced theories related to public transportation and conducted research on historical development, major concepts and contents. Through this, we analyzed the development of the station area in downtown Korea and the detailed planning of the new mini-town, and conducted empirical research by applying TOD theory to the development of the station area in the industrial complex.

Kwon Young-jong and Oh Jae-hak (2004) studied public transportation-oriented urban development and transportation system construction. Researchers have proposed problems and improvements in existing (new) urban development and domestic urban development at the legal and institutional level in terms of TOD.

Seong Hyun-gon, Park Jee-hyung, and Kim Dongjun (2007) conducted a study on the effectiveness analysis of public transport-oriented urban development and the application of guidance techniques. Here, in addition to urban planning and design-side induction techniques for TOD revitalization, accessible induction techniques in terms of transportation are considered together to devise institutional improvements.

As a result of reviewing the above research, it is rare to empirically analyze cases of TOD application focusing on station influence areas. Therefore, it is necessary to examine domestic and foreign TOD cases applied to existing station areas in detail in consideration of the land use characteristics of urban plans and public transportation characteristics of transportation plans, and present important directions and policy implications.

\section{ANALYSIS OF TOD APPLICATION CASES IN DOMESTIC AND FOREIGN STATIONS}

\section{A. Criteria and Content for Case Selection}

In Korea, the development of station influence areas is becoming an important direction for urban development and maintenance policies to form a public transport-oriented urban spatial structure with the opening of the high-speed railway era. To this end, the centrality of public transportation nodules is secured by closely integrating high-speed railway stations. Against this backdrop, case areas in domestic and foreign stations were selected from the perspective of representation of high-speed railway stations, ease of data collection, and feasibility of 
research targets.

TOD is a concept of planning to achieve the efficiency and comfort of urban spatial structure through the development of dense transportation systems and land use centered on public transportation. Therefore, the application factors of TOD to the station area were classified into three major categories: the land use characteristics of urban planning, the public transportation characteristics of transportation plans, and the legal sector.

In this study, case areas were analyzed using measurement items that have proven reliability and feasibility in existing studies, focusing on land use characteristics and public transportation characteristics as key factors for TOD.

In order to analyze the application cases of TOD to the high-speed railway station area in Table 2. it is divided into domestic and foreign sectors. In the domestic high-speed railway station area, there is a key facility opening, an example of developing an existing history aged by private capital into a private sector history with complex functions.

The characteristic of the existing urban redevelopment type is that it is behind the declining existing urban area. The development of a new city is the case of creating a planned and systematic new town using the potential of the station influence area along with the construction of railway history. Overseas high-speed railway stations have analyzed Tokyo Station, France-Reilly Station, Hong Kong Station and Guryong Station in Hong Kong.

Table 1. TOD APPLICATION IN CASE AREA ANALYSIS

\begin{tabular}{|c|c|c|}
\hline \multicolumn{2}{|c|}{ TOD Applications variable } & TOD Measurements \\
\hline \multirow{3}{*}{$\begin{array}{c}\text { Land } \\
\text { Utilization } \\
\text { Characteristic }\end{array}$} & $\begin{array}{l}\text { Land Use } \\
\text { Density }\end{array}$ & $\begin{array}{l}\text { Public transportation demand } \\
\text { density, infrastructure capacity } \\
\text { density, barrier-free planning, } \\
\text { development density, } \\
\text { development } \\
\text { pedestrian road }\end{array}$ \\
\hline & $\begin{array}{l}\text { Land Use } \\
\text { Complexity }\end{array}$ & $\begin{array}{l}\text { - Mixed land use, complex } \\
\text { standards between uses and } \\
\text { facilities, community plans, } \\
\text { regional complex plans, } \\
\text { specialized plans, specialized } \\
\text { plans; and special plan zones }\end{array}$ \\
\hline & $\begin{array}{l}\text { Land Use } \\
\text { Publicity }\end{array}$ & $\begin{array}{l}\text { Connection of public facilities, } \\
\text { utilization of public spaces, and } \\
\text { comfort of public spaces }\end{array}$ \\
\hline \multirow{3}{*}{$\begin{array}{l}\text { the Public } \\
\text { Traffic } \\
\text { Characteristic }\end{array}$} & $\begin{array}{c}\text { Public } \\
\text { transportation }\end{array}$ & $\begin{array}{l}\text { - Bus routes, } \\
\text { (railroads), } \\
\text { transportation } \\
\text { and service }\end{array}$ \\
\hline & $\begin{array}{l}\text { Public } \\
\text { transportation } \\
\text { facilities }\end{array}$ & $\begin{array}{l}\text { - Bus-only lanes, bus stops, } \\
\text { railway facilities, barrier-free } \\
\text { facilities, information systems, } \\
\text { access road facilities }\end{array}$ \\
\hline & $\begin{array}{l}\text { Traffic } \\
\text { demand } \\
\text { management }\end{array}$ & $\begin{array}{l}\text { Congestion charge, parking } \\
\text { management, } \\
\text { transportation zone, traffic } \\
\text { congestion, one-way traffic }\end{array}$ \\
\hline
\end{tabular}

\section{B. Review of domestic application cases}

Number In the application of the high-speed railway station area in Korea, Yongsan Private Station Station has high utilization of facilities against the backdrop of high-density hinterland complexes, but it has been developed mainly in department stores and movie theaters.

As the application factors of TOD considered in Yongsan private sector history, the density of land use due to the density of demand for public transportation, the complexity of land use, and complex standards between facilities may be identified.

Starting with the establishment of a new station incident, the Daejeon Station Area is seeking to develop the surrounding area. In terms of inducing balanced development of new and $\mathrm{Gu}$ cities, the density of land use and the complexity of land use according to the characteristics of land use may be considered as the main TOD application factors.

Due to the lack of access to existing urban areas, the complexity of land use was considered as a TOD application factor to induce workplace balance through mixed land use and to establish regional complex plans. For the characteristics of public transportation, all three case areas may be considered in common with public transportation and transportation demand management techniques.

Table 2. APPLICATION OF TOD IN DOMESTIC HIGH SPEED RAIL STATION AREA

\begin{tabular}{|c|c|c|c|}
\hline $\begin{array}{l}\text { Case } \\
\text { area }\end{array}$ & $\begin{array}{c}\text { Developme } \\
\text { nt type }\end{array}$ & Main contents & $\begin{array}{c}\text { TOD } \\
\text { applicable } \\
\text { elements }\end{array}$ \\
\hline $\begin{array}{c}\text { Yongsan } \\
\text { private } \\
\text { station } \\
\text { area }\end{array}$ & $\begin{array}{l}\text { Open key } \\
\text { facilities }\end{array}$ & $\begin{array}{l}\cdot \text { Four stories } \\
\text { underground and } \\
\text { ten stories above } \\
\text { ground } \\
\text {-Electronic stores, } \\
\text { clothing stores, } \\
\text { business, culture, } \\
\text { and assembly } \\
\text { facilities } \\
\text {-Example of } \\
\text { developing old } \\
\text { history as a } \\
\text { private history of } \\
\text { complex functions } \\
\text { (Seoul Station, } \\
\text { Yongsan Station) } \\
\text { - Complexity of } \\
\text { land use }\end{array}$ & $\begin{array}{l}\text { Complexity } \\
\text { of land use } \\
\text {-Special } \\
\text { planned area } \\
\text {-Considering } \\
\text { development } \\
\text { density and } \\
\text { development } \\
\text { type by use } \\
\text {-Land } \\
\text { efficiency } \\
\text { complexation } \\
\text { Determinatio } \\
\text { n of three- } \\
\text { dimensional } \\
\text { land use plan }\end{array}$ \\
\hline $\begin{array}{c}\text { Daejeon } \\
\text { station } \\
\text { area }\end{array}$ & $\begin{array}{l}\text { Existing } \\
\text { city center } \\
\text { Redevelop } \\
\text { ment type }\end{array}$ & $\begin{array}{l}\text {-Creating } \\
\text { historical facilities } \\
\text { step by step } \\
\text {-Creating } \\
\text { integrated history, } \\
\text { main history, and } \\
\text { private history } \\
\text {-Sales, work, } \\
\text { medical, } \\
\text { accommodation } \\
\text { - Residential } \\
\text { environment } \\
\text { improvement } \\
\text { project, housing } \\
\text { redevelopment } \\
\text { project } \\
\text {-A large-scale } \\
\text { urban }\end{array}$ & $\begin{array}{l}\text {-Density of } \\
\text { land use } \\
\text {-Induce } \\
\text { balanced } \\
\text { development } \\
\text { of new and } \\
\text { old urban } \\
\text { areas } \\
\text {-Publicity of } \\
\text { land use } \\
\text {-Connectivity } \\
\text { with public } \\
\text { facilities }\end{array}$ \\
\hline
\end{tabular}




\begin{tabular}{|l|l|l|l|}
\hline & & $\begin{array}{l}\text { development } \\
\text { project to } \\
\text { revitalize urban } \\
\text { centers } \\
\text { Part of }\end{array}$ & \\
\hline $\begin{array}{l}\text { Gwngmy } \\
\text { eong } \\
\text { station } \\
\text { area }\end{array}$ & $\begin{array}{l}\text { - Location of } \\
\text { central commerce, } \\
\text { themed industries, } \\
\text { and residential } \\
\text { complexes } \\
\text {-Complex } \\
\text { complex for } \\
\text { buffering } \\
\text { commercial and } \\
\text { residential } \\
\text { functions } \\
\text { - Residential and } \\
\text { commercial } \\
\text { complex layout }\end{array}$ & $\begin{array}{l}\text { Complexity } \\
\text {-Direct stock } \\
\text { balance } \\
\text { induction for } \\
\text { mixed land } \\
\text { use } \\
\text {-Regional } \\
\text { complex plan } \\
\text {-Connection } \\
\text { with public } \\
\text { transportation }\end{array}$ \\
& $\begin{array}{l}\text { New Town } \\
\text { Developed }\end{array}$ \\
\hline $\begin{array}{l}\text { Data: After reviewing the plan and report of each case area, it is } \\
\text { revised and supplemented for conformity with this study. }\end{array}$ \\
\hline \multicolumn{3}{|l}{} \\
\hline
\end{tabular}

\section{Review of overseas application cases}

Japan's Tokyo Station Station area was transferred to related companies after the privatization of JR. As a result, legal regulations related to railway unit projects were eased and the direct management method of developing and operating the station authority was changed. In other words, as it is operated as a private train, the development of station areas is gradually taking place based on business feasibility.

Tokyo Station Area is a representative example of the development of underground stations that developed logistics, transfers, and commercial functions underground, and transfers between means of transportation take place in a single building. This is an example of a mix of facilities and uses in applying TOD, considering the type of transfer facility and through the complexity of land use.

In the case of the development of the Lily-Europe Station in Lillisi, France, as a means of public maintenance and supply of land, the public entity acquired land in a certain area and implemented the maintenance project. Since then, it has contributed to preventing reckless development and improving the systematic urban environment by using the Consultative Maintenance Zone System (ZAC)3, a system that is transferred to the construction entity.

This station area is one of the most representative examples of complex station area development as part of a large-scale urban planning project. As TOD elements, the complexity of land use, the public nature of land use, and the link between public transportation and green transportation can be identified.

Hong Kong is a city that reorganizes its spatial structure into a railway-centered public transportation system for efficient land use in a small city. Urban development projects are being carried out in connection with railway network development projects. In particular, to secure stable development profits and finances, the company is promoting the $\mathrm{R}+\mathrm{P}$ Development Model 4 (Rail+Property
Development), which integrates railway operation and real estate development projects.

At this time, the station area development plan includes a complex use development plan that includes commercial, business, culture, and housing in historical facilities and surrounding areas. This will secure transportation infrastructure and improve accessibility, saving time and money, and improving the value of land. The demand for use of public transportation can be secured due to workers or residents of facilities near the station area, thereby increasing profitability.

In terms of recovering development profits, public institutions improve the urban environment and recover the profits from suppressing speculation and developing station areas to railway projects through land regulations. As a result, the effect of applying TOD is expected to be greatly increased due to the effect of further increasing public transportation of public transportation.

Table 3. APPLICATION OF TOD IN OVERSEAS HIGH SPEED RAIL STATION AREA

\begin{tabular}{|c|c|c|c|}
\hline $\begin{array}{l}\text { Case } \\
\text { area }\end{array}$ & $\begin{array}{l}\text { Development } \\
\text { type }\end{array}$ & Main contents & $\begin{array}{c}\text { TOD } \\
\text { applicable } \\
\text { elements }\end{array}$ \\
\hline $\begin{array}{l}\text { Japan } \\
\text { Tokyo } \\
\text { Station } \\
\text { Station } \\
\text { area }\end{array}$ & $\begin{array}{l}\text { New Town } \\
\text { Developed }\end{array}$ & $\begin{array}{l}\text {-Area: 140ha } \\
\text {-Private project } \\
\text { promotion } \\
\text { method } \\
\text { - Development } \\
\text { of representative } \\
\text { underground } \\
\text { rights developed } \\
\text { in underground } \\
\text { spaces for } \\
\text { logistics, } \\
\text { transfer, and } \\
\text { commercial } \\
\text { functions } \\
\text {-Transfer } \\
\text { between each } \\
\text { means of } \\
\text { transportation } \\
\text { takes place in } \\
\text { one building as } \\
\text { an integrated } \\
\text { transportation } \\
\text { center. }\end{array}$ & $\begin{array}{l}\text {-Public } \\
\text { transportation } \\
\text { characteristics } \\
\text {-Considering } \\
\text { transfer facility } \\
\text { type of transfer } \\
\text { facility } \\
\text { - Land use } \\
\text { characteristics } \\
\text {-Complexity of } \\
\text { land use } \\
\text { (Mixing und } \\
\text { facilities and } \\
\text { uses through } \\
\text { complexation } \\
\text { as a regional } \\
\text { complex plan) }\end{array}$ \\
\hline $\begin{array}{c}\text { France } \\
\text { Lily.- } \\
\text { European } \\
\text { Station } \\
\text { Station } \\
\text { area }\end{array}$ & $\begin{array}{l}\text { New Town } \\
\text { Developed }\end{array}$ & $\begin{array}{l}\text {-Area: 60ha } \\
\text {-A } \\
\text { representative } \\
\text { example of } \\
\text { complex station } \\
\text { area } \\
\text { development as } \\
\text { part of a large- } \\
\text { scale urban } \\
\text { planning } \\
\text { project. } \\
\text {-Creation of } \\
\text { complex } \\
\text { commercial } \\
\text { districts, } \\
\text { business } \\
\text { districts, and } \\
\text { urban parks }\end{array}$ & $\begin{array}{l}\text { - Land use } \\
\text { characteristics } \\
\text {-Complexity of } \\
\text { land use } \\
\text {-Publicity of } \\
\text { land use } \\
\text {-Public } \\
\text { transportation } \\
\text { characteristics } \\
\text {-Green traffic } \\
\text { (Public } \\
\text { Transportation } \\
\text { to Green } \\
\text { Transportation) }\end{array}$ \\
\hline $\begin{array}{c}\text { Hong } \\
\text { Kong } \\
\text { (Hong } \\
\text { Kong } \\
\text { Station, } \\
\text { Guryong } \\
\text { Station) }\end{array}$ & $\begin{array}{l}\text { Existing urban } \\
\text { redevelopment } \\
\text { type }\end{array}$ & $\begin{array}{l}\text { Hong Kong } \\
\text { Station } \\
2 \text { Composite } \\
\text { development of } \\
\text { the New } \\
\text { International } \\
\text { Financial Center } \\
\text { to expand CBD } \\
\text { around two } \\
\text { railway stations }\end{array}$ & $\begin{array}{l}\text { - Land use } \\
\text { characteristics } \\
\text {-Complexity of } \\
\text { land use } \\
\text {-Public } \\
\text { transportation } \\
\text { characteristics } \\
\text {-Planning } \\
\text { considering } \\
\text { transfer facility }\end{array}$ \\
\hline
\end{tabular}




\begin{tabular}{|c|c|c|c|}
\hline & & $\begin{array}{l}\text {-Three- } \\
\text { dimensional } \\
\text { complex transfer } \\
\text { system in a } \\
\text { single building } \\
\text {-Guryong } \\
\text { Station } \\
\text { 4Complex } \\
\text { development } \\
\text { centered on } 4 \\
\text { transportation } \\
\text { platforms } \\
\text {-Establishing a } \\
\text { district plan } \\
\text { designated as a } \\
\text { comprehensive } \\
\text { development } \\
\text { zone and } \\
\text { establishing a } \\
\text { three- } \\
\text { dimensional } \\
\text { land use plan }\end{array}$ & $\begin{array}{l}\text { type } \\
\text { (Compound } \\
\text { transfer center, } \\
\text { Public } \\
\text { transportation } \\
\text { transfer center, } \\
\text { transfer } \\
\text { terminal, } \\
\text { transfer } \\
\text { parking lot) }\end{array}$ \\
\hline
\end{tabular}

\section{URban Policy Directions For TOD APPLICATION}

\section{A. Objectives and types of policies}

A Previously, it is possible to establish policy goals by identifying the application of TOD in highspeed railway stations at home and abroad based on land use and public transportation characteristics. In order to revitalize the local economy from the perspective of maximizing the efficiency of land use in station areas, it is necessary to promote it in the form of high-rise and dense compressed cities with complex urban functions. Adjacent areas of the station area require an appropriate level of dense development as continuous population growth and potential development demand are predicted.

In connection with urban readjustment promotion projects or station area development projects around the station area, the central function of the station area development is enhanced, the inflow population and the stable settlement of existing residents. It is important to consider the application of TOD, which is the development of integrated strategies between land-use plans and transportation plans during urban planning or urban readjustment, as the most important technique in station area development. Therefore, the direction of urban policy is presented considering the importance of land use and public transportation characteristics.

Table 4. MAJOR GOALS, CHARACTERISTICS AND PROJECTS OF URBAN POLICY

\begin{tabular}{|c|c|c|}
\hline $\begin{array}{c}\text { Policy } \\
\text { objectives }\end{array}$ & $\begin{array}{l}\text { Policy direction by } \\
\text { objectives }\end{array}$ & Major undertakings \\
\hline $\begin{array}{l}\text { land-use } \\
\text { efficiency } \\
\text { Maximize }\end{array}$ & $\begin{array}{lr}\text { - Maintenance } & \text { of } \\
\text { complex urban } \\
\text { functions } \\
\text {-High-rise and dense } \\
\text { compressed city } \\
\text { functions } \\
\text { - Residence }\end{array}$ & 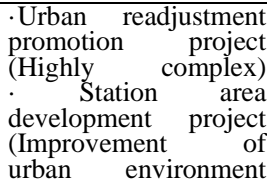 \\
\hline
\end{tabular}

\begin{tabular}{|c|c|c|}
\hline & $\begin{array}{lr}\text { maintenance } & \text { and } \\
\text { activation } & \text { around } \\
\text { station areas } & \\
\end{array}$ & $\begin{array}{lll}\text { adjacent } & \text { to } & \text { station } \\
\text { area) } & & \end{array}$ \\
\hline $\begin{array}{l}\text { transportation } \\
\text { network } \\
\text { Expansion }\end{array}$ & $\begin{array}{l}\text {-Improvement of } \\
\text { connected } \\
\text { transportation } \\
\text { system in } \\
\text { surrounding areas } \\
\text { - Repairing and } \\
\text { expanding public } \\
\text { transportation } \\
\text { facilities around the } \\
\text { station } \\
\text { - Enlargement of } \\
\text { public transportation } \\
\text { network linked to } \\
\text { stop stations and } \\
\text { surrounding areas }\end{array}$ & $\begin{array}{l}\text { - Diversification of } \\
\text { public transportation } \\
\text { methods } \\
\text { - Creation of } \\
\text { connected } \\
\text { transportation system } \\
\text { - Application of } \\
\text { transportation demand } \\
\text { management technique }\end{array}$ \\
\hline \multicolumn{3}{|c|}{$\begin{array}{l}\text { Data: Ministry of Land, Infrastructure and Transport, revised } \\
\text { and supplemented according to this study in an effective } \\
\text { development plan for the surrounding areas of high-speed } \\
\text { railways }\end{array}$} \\
\hline
\end{tabular}

\section{B. Toward TOD Policy in Urban Planning Dimensions}

The application of TOD through adjustment of the area of use requires a longitudinal upward precondition. First, the application of the blockbased regional system is minimized due to the increase in the use area. Only when the area of the project site is more than 10,000 square meters or is developed in block units can the area be raised.

Second, it is recommended that the subdivision and modification of the use area for general residential areas be reviewed by the local government's joint urban and architectural committee and, if necessary, adjusted in one step. However, when the standards for raising the usage standard are met exceptively, it may be raised by at least two levels after deliberation by the same deliberation committee. Third, considering the original location of the use area, general standards related to the use area shall be followed in the area surrounding the dedicated housing area and within the first type residential area.

In order to present the direction of application of TOD to station areas, it is required to analyze the development density centered on the realization rate of floor area ratio. The method of calculating incentives for development density is applied to the allowable and upper floor area ratios. The operational characteristics of the entitlement rate incentive are established and operated to achieve the entitlement rate in the reference dimension rate.

It is necessary to classify planned items by incentive type, and to establish a coefficient of incentives by item. Incentive items for achieving the objectives of district unit planning are determined in advance for specific application. It is reasonable to differentiate incentives by area of use and to differentiate the same blocks into mainline and backside. 


\section{Toward TOD Policy in Transportation Planning Dimensions}

As a transportation demand management technique in the station area, designation of zones dedicated to public transportation and traffic stabilization techniques can be applied. First, the Transit Mall has a positive effect of improving public transportation services, changing images, and commercial activities in public transportation zones, but it also has negative aspects such as congestion around public transportation zones and intensifying parking congestion.

Second, traffic calming techniques are a way to implement sustainable urban transportation, and interest in traffic stabilization techniques is increasing. Its purpose is to renovate existing facilities to reduce the speed of cars in residential areas, or to use them as a meeting place for residents or children's playgrounds rather than communication functions.

\section{Conclusion}

This study covers the application of public transport-oriented urban development and the direction of urban policy. The purpose of the study is to analyze the application of TODs around station areas at home and abroad, and to present the direction of land-use and public transportationrelated urban policies for the application of TODs in terms of urban planning and transportation planning.

The main contents consist of theoretical consideration of TOD, analysis of TOD application in station areas at home and abroad, and direction, implications, and conclusions of urban policies for TOD application. The study was conducted by reviewing existing literature, empirical consideration of existing cases, analysis of relevant administrative data and reports, and gathering expert opinions. As a result of the analysis of the case area, Yongsan Minja Station and Gwangmyeong Station Area were strongly applied to TOD's land use complex elements, and Daejeon Station Area was strongly applied to TOD's land use density and land use publicity elements. In foreign countries, Japan's Tokyo Station Area was applied with TOD's transit system, land-use complexity, publicity, green transportation characteristics, and Hong Kong Station Area's transit system considered as an important part of TOD.

In order to apply TOD to station areas, the policy objectives of increasing the efficiency of land use and expanding the transportation network must be established and the relevant policy directions must be identified. In terms of land use, policy directions such as complex urban functions, compressed cities, linked transportation systems, and expansion of public transportation networks can be considered. In order to apply TOD to station areas in terms of urban planning, adjustment of the use area and application of development density are required.

In addition, if the combined elements of TOD's land use are to be applied to the development of station areas, the change of station area use areas, the application of district unit planning system to station areas, and the implementation of station area development project system can be considered. Meanwhile, in order to apply TOD to station areas in terms of transportation planning, expansion and strengthening of public transportation such as expansion of urban railways, buses and transportation networks by station areas are required.

In order to apply transportation demand management techniques to TODs in station areas, measures such as the application of public transportation-only zones and the acceptance of traffic stabilization techniques are important. Finally, from the planning stage of TOD, legal and institutional foundation and maintenance are urgently needed at the central and local levels to ensure integration between land use and transportation plans.

The TOD application based on the development of station areas creates the public and profitable nature of land use, showing important implications for Korean urban policy as a means to revitalize urban functions. Accordingly, it is possible to consider the introduction of a three-dimensional urban planning system or the development of a compressed city based on the complexity of land use. This study is meaningful in terms of forming a basic theory for applying TOD techniques to station development in Korea, enhancing the rationality of TOD policy directions, and providing expertise to relevant researchers. Based on this study in the future, it is believed that further analytical studies on the development and application effects of TOD-specific techniques to apply TOD to station areas will be required.

\section{REFERENCES}

[1] Park, J.H. (2008). Impacts Analysis of TOD Planning Elements on Transit Ridership in Seoul Rail Station Areas, Department of Urban Engineering Graduateb School of Hanyang University

[2] Kwon, Y.J, Oh.J.H.(2004). A Study on the Urban Development and the Establishment of Transportation System for Public Transportation, Korea Transport Institute.

[3] Sung,H.G, Park,J.H, Kim,D.J.(2007). Impact analyses of transit-oriented development and revising current transportation and urban planning laws for its application in Korea, Korea Transportation Institute. 
[4] Lee, J.W.(2010). A study on planning techniques and regulatory improvements for enhancing multidimensional urban planning, Department of Urban Planning \& Development Management, Hanyang University.

[5] Cho,K.M.(2009). Analysis of Planning Factors for Transit-Oriented Development-A case of LU1 City Urban Regeneration Project, Incheon-, Department of Urban Planning Graduateb School of Inha University

[6] Cervero, et.al(2002). Transit-Oriented Development and Joint Development in the United States: A Literature Review. Transit Cooperate Research Program.

[7] Kenworthy, J., (2006). Urban Planning and Transport Paradigm shifts for Surviving the Post-Petroleum Age in Cities, Journal of Urban Technology, 14(2), 47-70.

[8] Peter Calthorpe.(1993). The Next American Metropolis: Ecology, Community and the American Dream. Princeton Architectural Press.

[9] Pendyala, R. (1998). "Causal analysis in travel behaviour Research: A cautionary note. In J. de D. Ortuzar, D.A. Hensher and S. Jara-Diaz (Eds.)",

Travel Behaviour Research: Updating the State of Play, 35-48. Pergamon, Oxford.

[10] Strathman, J., and Dueker, K. (1996). "Transit service, parking charges and mode choice for the journey-towork: An analysis of the 1990 NPTS.", Journal of Public Transportation, 1(1), 13-38. 